\title{
Criza familiei în România contemporană. $O$ analiză sociologică, pastorală și catehetică
}

\author{
Vasile CREȚU*
}

Abstract: Family crisis in contemporary Romania. A sociological, pastoral and catech etic alanalysis. The family has always had a central place in human history, and it has been seen as the most important social structure of all. The family is the most stable and oldest form of humanlife, guaranteeing the permanence of humanity, the evolution and the continuity of life in society. The social dimension of the family describes the system of relationships between couples, parents, children and other siblings. From a sociological perspective, the family is seen as the foundation of human society and contributes to its formation, because men, women and children are connected in a relationship only throught he power of thefamily. With in the family, they learn various types of cultures, normsand values that individuals must later put into practice in society, in order to contribute to the well-being and evolution of the community. The family, however, is influencedby a series of factors which became more visible in the recent years. The issue of migration, child abandonment, declining birthrates and nuptials, seen in terms of thesocial impact on families in Romania, is extremely serious not only now but in the longrun as well. Being a micro-society, the family under goes changes in its owndynamics due to changes in society and in the environments in which its members live andwork, but through the mechanism of self-regulation, adaptation, communication, its members can restore the stability.

Keywords: family, Romania, crisis, emigration, abandon, birthrates, marriage.

* Pr. conf. univ. dr., Facultatea de Teologie Ortodoxă „Justinian Patriarhul”, Universitatea București. 


\section{Introducere}

Familia a ocupat dintotdeauna un loc central în istoria umanităţii, fiind înțeleasă drept cea mai însemnată alcătuire socială. Din puncte de vedere sociologic, familia reprezintă un grup de persoane care conviețuiește după anumite tradiţii, reguli și obiceiuri și care creează o atmosferă de grup. Conform Elisabetei Stănciulescu, ,familia este o unitate socială constituită din adulți și copii, între care există relații de filiație - naturală sau socială indiferent de orice alte considerente"l.

Familia este de două tipuri: extinsă (patriarhală sau clasică) şi nucleară (de tip modern). Familia extinsă are un raport de întregparte cu cea nucleară. Familia extinsă este formată din rudele până la gradul IV (3 generații), care locuiesc împreună, regulile și îndatoririle fiind clar stabilite de către pater familiae. Regulile, concepțiile și normele sunt moștenite de la o generație la cealaltă, iarrelațiile dintre membrii ei sunt adesea constituite pe întrajutorare. Familia nucleară este formată din părinți și copii. Dinamica relațiilor diferă faţă de familia clasică, acestea fiind mai strânse, atenția concentrându-se în principiu pe creșterea și educarea armonioasă a copiilor ${ }^{2}$. În ultimul secol au luat naștere și familiile monoparentale. Acestea sunt formate dintr-un singur părinte și unul sau mai mulți copii.

Familia este cea mai stabilă și veche formă de viață umană, garantând permanența umanității, evoluția și continuitatea vieții în societate. Dimensiunea socială a familiei descrie sistemul de relații între cupluri, părinți, copii și alți frați. Relațiile complexe sunt stabilite între soți, descendenți și membrii familiei nucleare sau alte relații îndepărtate. Fiecare membru al familiei face parte din mai multe sisteme și subsisteme care implică asumarea diferitelor stări, roluri și interacțiuni.

1 Elisabeta Stănciulescu, Sociologia educației familiale, vol. I, Iași, Edit. Polirom, 2002, p. 46.

${ }^{2}$ Mihai Diaconu, Sociologia educației, București, Edit. ASE, 2004, p. 146. 
Criza familiei în România contemporană.

O analiză sociologică, pastorală și catehetică

Din perspectivă sociologică, familia este privită ca temelia societății umane și contribuie la formarea ei, deoarece bărbații, femeile și copiii se leagă într-o relație doar prin familie. În cadrul familiei, ei învață diverse tipuri de culturi, norme și valori pe care indivizii ulterior trebuie să le pună în practică în societate, pentru a contribui la bunăstarea și evoluția comunității. De exemplu, părinții unui copil îl învață cum ar trebui să interacționeze cu oamenii într-o manieră politicoasă, să-i trateze întotdeauna pe ceilalţi cu respect și amabilitate. Când înțelege aceste valori în familia sa, abia atunci este capabil să le implementeze eficient în cadrul societății și în relațiile cu ceilalți indivizi ${ }^{3}$.

Ultimul deceniu al secolului al XX-lea și primele două decenii din secolul al XXI-lea pot fi comparate cu o ,punte a suspinelor" de bucurie și suferință pentru foarte mulți români. Schimbările majore determinate de noua ordine socială, economică și politică au avut si au un impact multidimensional la nivelul societății românești. În continuare, voi prezenta câteva transformări majore prin care trece familia în România postcomunistă și consecințele vizibile pe care le provoacă aceste schimbări pe termen mediu și lung.

\section{Emigrația $^{4}$ și abandonul copiilor}

După 1989, fenomenul emigrației din România a atins pragul alarmant de peste $20 \%$ din populația activă a țării. Acest proces nu a înregistrat niciodată valori atât de ridicate, nici măcar în contextul celor două războaie mondiale, care au provocat mari tragedii şi dezechilibre în societate. De aceea, putem afirma că, pentru România, este un adevărat dezastru demografic că o parte semnificativă din forța de muncă a țării își desfăşoară activitatea în hotarele altui stat, ba, mai mult decât atât, stabilindu-se cu reședința

${ }^{3}$ Dumitru Popoviciu, Sociologia educației, Iași, Edit. Institutul European, 2003, p. 63.

${ }^{4}$ Unele dintre datele prezentate aici sunt preluate și adaptate din studiul nostru „Testele Pisa din 2018 - o radiografie a învățământului românesc actual”, în Anuarul Facultății de Teologie Ortodoxă a Universității din București, 2020, p. 423-425. 
și întreaga familie în respectivele țări, copiii se formează la școli străine, alături de colegi de alte naționalități, alterându-se astfel elementul național identitar.

Avem peste 3,4 milioane de români plecaţi la muncă în străinătate sau stabiliți definitiv acolo cu tot cu familii, ceea ce plasează România pe poziția a doua într-un top mondial al migrației. Cifrele vin de la Organizația Națiunilor Unite (ONU), ai cărei reprezentanți susțin că suntem întrecuți doar de Siria, stat lovit de un război civil. În procente, diaspora reprezintă $17 \%$ din populația totală a României. Concret, potrivit ultimului raport ONU referitor la migrație, cu date din 2015, România înregistrează a doua cea mai mare creștere a diasporei unei țări. Mai exact, țara noastră a înregistrat o creștere a migrației de $7,3 \%$ pe an, în timp ce pe primul loc este Siria cu 13,1\%, iar pe locul trei Polonia, cu 5,1\%. Experții Naţiunilor Unite notează că România are cea mai accelerată creștere a numărului de migranți într-un stat care nu s-a confruntat cu războiul. La rândul lor, românii consideră că sunt forțați să plece la muncă în străinătate pentru că și-au pierdut locurile de muncă sau li s-au diminuat semnificativ veniturile, iar şanse reale pentru un trai decent ar mai avea doar în străinătate ${ }^{5}$.

Diferența de venituri, șomajul, dorința de a avea o viaţă mai bună și sărăcia au făcut ca foarte mulți români să plece, căutând locuri de muncă în străinătate și căutând să ofere o viață mai bună copiilor și tinerilor care, de cele mai multe ori, rămân singuri sau în grija bunicilor și care devin expuși la mai multe riscuri, cum ar fi: abandon școlar, autoizolare, apariția unor tulburări emoționale și comportamentale. Plecarea unuia dintre părinți sau a ambilor provoacă urme adânci, de neînlocuit în evoluția copiilor care rămân acasă. Una dintre consecințele cu cele mai profunde implicații negative ale migrației românilor este că o mare parte a generaţiei actuale de copii din România crește fără sprijinul de neînlocuit al părinţilor.

5 https://m.adevarul.ro/news/eveniment/cum-ajuns-romanii-locul-doiin-lumeemigratie -motive-consecinte-1_599473bc5ab6550cb80c2cdc/index.html (accesat la data de 23.11.2020). 
Criza familiei în România contemporană.

O analiză sociologică, pastorală și catehetică

În ultimii 30 de ani, România a înregistrat cea mai mare rată de avorturi - majoritatea familiilor având cel mult un copil, divorțuri - ca urmare a unor agresiuni fizice, lipsuri materiale sau separării soților, copii abandonați după naștere sau lasați de părinții plecați la muncă în străinătate în grija bunicilor sau a rudelor, fie uitați în orfelinate. Așadar, România ocupă un loc fruntaș în ce privește rata abandonului şcolar, acest proces fiind foarte greu de stopat. Mulți părinți nu își pot trimite copiii la școală din cauza infrastructurii precare din satele izolate sau a lipsei resurselor financiare, unii copii muncind din greu în loc să meargă la școală sau rămânând acasă pentru a avea grijă de frații mai mici, cât timp părinții muncesc.

O scrisoare publică semnată în anul 2019 de către două senatoare USR, Silvia Dinică și Florina Presadă, ne aduce în atenție o realitate îngrijorătoare: România înregistrează una dintre cele mai ridicate rate din Uniunea Europeană în ceea ce privește părăsirea timpurie a școlii (16.4\% în anul 2018), mai ales în zonele rurale $(25,4 \%$ în anul 2018) sau în rândul copiilor de etnie romă (77\% în 2016). Unele dintre cele mai scăzute rate pentru cuprinderea în învățământul preșcolar și terțiar, învățarea pe tot parcursul vieții, rezultatele testelor internaționale PISA și procentul din PIB alocat învățământului le regăsim tot în țara noastră ${ }^{6}$.

Sociologul Dumitru Sandu, profesor la Universitatea din București, a susținut în aprilie 2018 o prezentare pe tema migrației tinerilor români, într-o conferință internațională organizată la Bruxelles în cadrul proiectului european Youth Mobility ${ }^{7}$. El afirmă că, printre cei care pleacă din România, majoritari sunt tinerii. Principalul segment de vârstă al celor care migrează a urcat de la 2124 de ani la 25-29 de ani. Concret, dacă îi întrebi pe tinerii români ce

${ }^{6}$,Fenomenul Brăila: USR îi cere Ecaterinei Andronescu stoparea fenomenului de excluziune educațională în școli”, pe Mediafax.ro, disponibil la https://www.mediafax.ro/social/fenomenul-braila-usr-ii-cere-ecaterinei-andronescustoparea-fenomenului-de-excluziune-educationala-in-scoli-18230141 (accesat la data de 22.10.2020).

7 https://www.academia.edu/36446004/ROMANIAN_MIGRATION_FIELDS _ON_THE_MOVE (accesat la data de 21.10.2020). 
intenție au pentru următorul an, 23\% îți vor spune că au de gând să plece. Dacă îi întrebi ce au de gând pentru următorii 5 ani, aproape jumătate $(47 \%)$ îți vor spune că au de gând să plece. Realitatea socială e de multe ori mai inteligentă decât oamenii politici și găsește soluții. Oamenii nu așteaptă corpuri instituționale care se mișcă greu, iar una dintre soluțiile găsite este migrația circulară - un gen de euronavetism, un du-te/vino între Romania și alte țări - care este în creștere. Spre exemplu: medicul care își ia câteva luni de concediu și merge să lucreze în străinătate pentru a-și completa veniturile ${ }^{8}$.

Profesorul Dumitru Sandu, directorul Centrului pentru Studiul Migrației din cadrul Universităţii din București, ajunge la o concluzie surprinzătoare: cu cât euronavetismul va fi mai puternic, cu atât probabilitatea de plecare definitivă sau pe termen lung va fi mai mică. $\mathrm{O}$ altă concluzie la care ajunge universitarul bucureștean este că tânărul din România pleacă dintr-un cumul de motive. Pe primul loc se situează locul de muncă. Pe locul doi, tinerii români pleacă acolo unde au prieteni, familie și oportunități de educație. În sfârşit, pe locul trei (ceea ce ne interesează foarte mult atunci când ne gândim la soluții) este motivația legată de cum funcționează instituțiile publice din România (de la primărie, la Parlament, la partide politice, la judecătorii etc). Concluzia finală a acestei cercetări academice este că România nu are nici politică de migrație, nici strategii de rezolvare a problemelor asociate cu migrația. Problemele sunt atât de grele și de diversificate, încât e nevoie destrategii pe segmente, pe categorii de migranți: o strategie pentru lucrători în construcții, una pentru domeniul sanitar etc ${ }^{9}$.

În data de 29 decembrie 2020, Mișcarea pentru Dezvoltarea Moldovei a organizat o dezbatere online având ca temă ,De ce nu se întorc migranții. Efectele depopulării cauzate de migrația economică în Occident (1990-2020)"'10. Sociologul Dumitru Sandu a vorbit

8 https://www.academia.edu/36446004/ROMANIAN_MIGRATION_FIELDS _ON_THE_MOVE (accesat la data de 21.10.2020).

9 https://www.academia.edu/36446004/ROMANIAN_MIGRATION_FIELDS _ON_THE_MOVE(accesat la data de 21.10.2020).

10 http://www.miscareamoldova.ro/adevarul-ro-efectele-depopularii-cauzate-demigratia-economica-in-occident/ (accesat la data de 07.12.2021). 
Criza familiei în România contemporană.

O analiză sociologică, pastorală și catehetică

despre consecințele migrației externe: depopulare, îmbătrânire demografică și consecințele economice. Profesorul a prezentat o hartă a României care arată că județele Moldovei (Botoșani, Iași, Vaslui, Bacău, Vrancea și Galați) sunt cele mai afectate de migrația externă, în special prin plecarea românilor din mediul rural la muncă în țările Europei Occidentale. La cele mai afectate județe de migrația din regiunea Moldovei se adaugă și județele Covasna, Dâmbovița și Sălaj. În analiza efectelor migrației externe din mediul rural, sociologul D. Sandu a utilizat un model de regresie cu variabile multiple: apropierea localității rurale de cel mai apropiat centru urban, nivelul de dezvoltare economică al localităţii rurale, vârsta medie a populației la începutul perioadei de referință. Acest model statistic explică de ce migrația externă din satele județelor Botoșani, Iași, Vaslui, Bacău, Vrancea și Galați este masivă, în comparație cu județele Suceava şi Neamț: decalajul de dezvoltare economică dintre localităţile urbane și cele rurale ale județelor Suceava și Neamț este mai mic decât în celelalte județene analizate. În sinteză, moldovenii de la sate emigrează în masă din cauza nivelului de trai scăzut, a sărăciei, în căutarea unor locuri de muncă care să le aducă venituri mai mari pentru rezolvarea problemelor $\mathrm{cu}$ care se confruntă în localitățile de reședință ${ }^{11}$.

Prin urmare, regiunile extracarpatice sunt cele mai puţin dezvoltate, cele mai sărace județe fiind: Botoșani, Iași, Suceava, Bacău, Vaslui, Vrancea, Buzău, Ialomița, Călărași, Giurgiu, Teleorman, Olt și Mehedinți. Această lipsă de dezvoltare este manifestată și în ceea ce privește produsele și serviciile culturale oferite. Județele cu nivel mediu-inferior de dezvoltare sunt situate majoritar în zona vestică a Moldovei, în banda care începe cu Suceava și merge continuu până la Vrancea, cu extindere în regiunile sudice prin Buzău, Dâmbovița și Vâlcea; maximul de dezvoltare socială se înregistrează în Sibiu, Brașov, Cluj, Timiș, București.

Pe de altă parte, nu este un secret pentru nimeni că România face, din 1990 încoace, obiectul unor posibile operațiuni organizate

11 http://www.miscareamoldova.ro/adevarul-ro-efectele-depopularii-cauzate-demigratia-economica-in-occident/ (accesat la data de 07.12.2021). 
de furt al creierelor, care, deși sunt derulate de instituții private, se bucură de sprijinul tacit al organelor unor state partenere (până la nivelul ambasadelor din România). Ar însemna să dăm dovadă de naivitate dacă am crede că putem opri exodul creierelor din România $^{12}$. Și state mult mai dezvoltate, cum sunt Franța, Marea Britanie sau Germania, fac - la altă scară - obiectul acestui fenomen, atât din partea SUA, cât și din partea unor state puternic dezvoltate din punct de vedere economic (în primul rând China).

Asistăm astăzi la o migrație în masă și la un abandon familial crescut: „foarte mulți români sunt dezamăgiți de România și aleg exilul. Semnificativ este faptul că cei mai mulți dintre cei nemulțumiți de absența locurilor de muncă sau de proasta salarizare din România au un nivel modest al pregătirii de specialitate. Domeniile în care lucrează în străinătate sunt pe măsura pregătirii lor: agricultură, construcții, îngrijire persoane vârstnice și transport"13.

Migrația generează câteva consecințe negative pentru familie, printre care se identifică ,scindarea permanentă a familiei, scindare care este de două feluri: fie a plecat un părinte, iar celălalt a rămas acasă cu copiii, fie au plecat amândoi părinții și au rămas acasă copiii (în cele mai fericite cazuri, în grija bunicilor, iar în multe cazuri, singuri), aceasta de-a doua situație fiind dezastruoasă pe termen lung. Divorțul este un rezultat fatal al problemei enunțate mai sus, fiind produs de separarea îndelungată, dar și de anumite tentații pe care Occidentul le oferă celor plecați acolo la muncă. Efectele divorțului asupra copiilor sunt dezastruoase, culminând cu

12 Dau numai un exemplu la îndemână. În timp ce, pe de-o parte, universitățile românești fac obiectul unei permanente denigrări în mass-media, târgurile universităților străine în România sunt organizate fără nici o restricție, ba chiar cu sprijinul autorităților. Dacă aceste activități, care sunt în mod direct activități de braindrain, ar fi supra-impozitate (ca produsele de lux sau jocurile de noroc), impactul lor ar scădea. Dacă publicitatea pentru asemenea activități de recrutare de creiere ar fi supra-impozitată, ecoul ei public ar dispărea.

13 Nicu GAVRILUȚă, ,Criza spirituală a satului românesc contemporan. Diagnostic şi terapii religioase", în †VARLAAM Ploieșteanul, Nicuşor BELDIMAN (coord.), Satul românesc: vatră a plămădirii, păstrării și promovării ființei naționale și a credinței ortodoxe, București, Edit. Basilica, 2019, p. 312. 
Criza familiei în România contemporană.

O analiză sociologică, pastorală și catehetică

disoluția familiei. Pe lângă divorțurile pronunțate, există foarte multe cazuri de familii separate de mult timp, dar care încă nu au divorțul hotărât de o instanță judecătorească, însă efectele pentru familie și,mai ales, copii, sunt la fel de grave: lipsa de atenție asupra educației copiilor din țară, lipsa afectivității pentru copii, părinții neputând fi înlocuiți de rude sau prieteni"14.

La scară națională, fenomenul copiilor care au cel puțin un părinte plecat în străinătate este estimat a fi caracteristic pentru aproximativ 350000 decopii, respectiv afectați la momentul derulării cercetării. Mai mult de o treime dintre aceștia,adică aproximativ 126000 de copii, sunt afectați de migrația ambilor părinți. Din punct de vedere geografic, cea mai afectată zonă este Moldova cu aproape 100000 de copii. Cifre similare sunt în Transilvania și Oltenia (adică 50000) și Muntenia (cu 55000 de copii afectați de fenomen) ${ }^{15}$.

Majoritatea părinților migranți au sub 40 de ani, atât mame cât și tați (78\% respectiv 63\%). Diferențe apar în termeni de interval de vârstă, procentajele fiind similare în tranșa 30-40 de ani (55\% respectiv 52\%), dar înjumătățindu-se pentru tați în tranșa 2029 de ani (23\% pentru mame şi $11 \%$ pentru tați). Foarte rar (7\%) părinții informează autoritățiledespre intenția lor de a pleca în străinătate. Mai mult, de obicei părinții nu își pregătesc în nici un fel copiii înainte de a pleca. De asemenea, copiii implicaţi în procesul de luare a deciziei de a migra sunt în număr foarte mic: pe grupe de vârstă rezultatele arată că aproximativ $16 \%$ din copii sub 6 ani, 19\% din copii peste 10 și sub 14 ani, și 34\% din copii peste 15 si sub 17 ani sunt consultaţi de părinți înainte de a pleca ${ }^{16}$.

Absența mamei din familie în procent aproape asemănător cu absența tatălui (38,8\% dintre copii au mama plecată în străinătate și $38 \%$ au tatăl plecat) indică un risc accentuat pentru copii, luând în considerare modelul tradiţional al familiei în care mamele dețin rolul cel mai important în creșterea și educarea copiilor; în același

14 Vasile PoP, „Familia creștină - imperativul misionar al Bisericii în societatea contemporană. Accente și remedii misionare", în Glasul Bisericii, 1-6/2018, p. 111.

${ }^{15} \mathrm{https}$ ///www.unicef.org/Raport_final_HAC.pdf (accesat la data de 10.01.2021).

${ }^{16} \mathrm{https} / / /$ www.unicef.org/Raport_final_HAC.pdf (accesat la data de 10.01.2021). 
timp, acesta este unul dintre factorii importanți care contribuie la schimbarea modelului familiei:

- 8,4\% dintre copii declară că au fost lăsați singuri de către părinții plecați la muncă în străinătate;

- 24\% dintre copii declară că vorbesc periodic;

- $(13 \%)$ sau rar cu părinții lor;

- 44\% dintre copii declară că au observat modificări în comportamentul celorlalți față de ei; dintre modificările sesizate pe primul loc se situează faptul că ceilalți se poartă mai frumos cu ei fie pentru a-i menaja, fie pentru a obține daruri;

- 45,67\% dintre copii declară că le lipsesc foarte mult părinții; se remarcă faptul că cei mai mulți dintre aceștia au mamele plecate;

- 15,29\% dintre copii consideră că relațiile dintre părinții lor sau deteriorat;

- 27,42\% dintre copii afirmă că părinții lor plecați la muncă în străinătate nu intenționează să se întoarcă definitiv în țară; $42 \%$ nu știu dacă părinții lor se vor întoarce;

- 31\% dintre copii doresc să plece în străinătate, din care 15\% doresc să plece în străinătate pentru a munci ${ }^{17}$.

\section{Schimbări majore ale natalității și nupțialității}

Anul 2020 a fost anul cu cele mai puține nașteri din 1967 până în prezent. S-au născut 163 de mii de copii, cu peste 40 de mii mai puțini ca anul $2019^{18}$. Am luat ca reper 1967 pentru că este anul următor decretului dat de Ceauşescu prin care a interzis avorturile și metodele contraceptive. Potrivit datelor Academiei Române și INS, anual între 1970 și 1989 s-au născut, în medie, câte 360 de mii de copii. În 1989 s-au născut 369.000 de copii, iar în 1990, numărul a

${ }^{17} \mathrm{https} / / /$ www.unicef.org/Raport_final_HAC.pdf (accesat la data de 10.01.2021).

$18 \mathrm{https} / / / \mathrm{insse} . \mathrm{ro} / \mathrm{cms} / \mathrm{ro} / \mathrm{content} / \mathrm{mi} \% \mathrm{C} 8 \% 99$ carea-natural\%C4\%83-popula\%C $\% \%$ 9Biei-72 (accesat la data de 10.12.2020). 
Criza familiei în România contemporană.

O analiză sociologică, pastorală și catehetică

fost de $314.746^{19}$. De atunci natalitatea a scăzut aproape continuu, cu ușoare reveniri. Până acum, însă, 163.320 de nou-născuți într-un an nu am mai avut din anii ' 60 .

Cifrele arată că scăderea natalității nu a fost influențată de pandemie sau de actuala criză sanitară și economică decât pentru nașterile înregistrate în luna decembrie 2020, acei copii fiind concepuți cu 40 de săptămâni înainte, cât este durata unei sarcini la termen, adică în luna martie 2020. Cu alte cuvinte, copiii născuți în intervalul ianuarie-decembrie 2020 au fost concepuţi în perioada mai 2019 - martie 2020. Lipsa a peste 40 de mii de copii dintr-o generație are un impact direct asupra sistemului de educaţie. La grădiniţă, de exemplu, în anul în care aceștia vor ajunge în învățământul preșcolar, vor fi cu cel puțin 1.600 de grupe de câte 25 de copii mai puține ca pentru cei din anul anterior. La fel și pentru momentul în care această generație va ajunge la școală.

Începând cu anul 1992, asistăm la o creștere a numărului de nașteri în afara căsătoriei, proporția lor progresând de la 15\% (1992) la 30,1\% (2019). Paradoxal, mai afectat de acest fenomen a fost mediul rural, considerat mai conservator și apărător al tradițiilor. În 2019, din totalul copiilor născuți în rural, 36,5\% au fost născuți de mame necăsătorite. Cea mai mare parte a copiilor născuţi în afara căsătoriei provin de la tinerele până în 25 ani (aproximativ 60,2\%) ${ }^{20}$.

Cât privește nupțialitatea (denumirea statistică a ratei căsătoriilor), românii se căsătoresc la vârste mai înaintate față de acum 30 de ani și divorțează mai greu, un semn al schimbărilor fundamentale prin care a trecut societatea românească după Revoluția din 1989, arată o analiză Frames ${ }^{21}$. Statisticile oficiale arată că, în 1990, tinerii erau mult mai deciși să își unească viețile decât în prezent. Bărbații se căsătoreau, în medie, la 25 de ani, iar femeile la 22 de ani. De atunci, vârsta medie a tinerilor aflați la

19 https://insse.ro/cms/ro/content/mi\%C8\%99carea-natural\%C4\%83-popula\%C8\% 9Biei-72 (accesat la data de 10.12.2020).

20 https://insse.ro/cms/ro/content/mi\%C8\%99carea-natural\%C4\%83-popula\%C8\% 9Biei-72 (accesat la data de 10.12.2020).

${ }^{21} \mathrm{http} / / /$ framesmedia.ro/2020/02/14/ (accesat la data de 14.12.2020). 
prima căsătorie a crescut vertiginos, ajungând, în 2018, la 31,9 ani în cazul bărbaților, și la 28,7 ani în cazul femeilor. Analiza Frames arată, totodată, că numărul căsătoriilor a scăzut vertiginos în ultimii 30 de ani. Dacă în 1990, la Oficiile de Stare Civilă erau înregistrate 192652 de căsătorii, în 2018 numărul acestora a scăzut cu aproape $50.000(143292)^{22}$.

Recordul negativ din punct de vedere al căsătoriilor a fost înregistrat în 2011, când Institutul Naţional de Statistică raporta un număr total de 105599 de căsătorii. Astfel, ,2010, 2011 şi 2012 au fost anii crizei economice, iar românii au resimţit din plin provocările acelor vremuri. Scăderea abruptă a numărului căsătoriilor este în strânsă legătură cu problemele financiare din acea perioadă, cu disponibilizările, cu tăierile de salarii, cu climatul de insecuritate socială", arată analiza Frames ${ }^{23}$.

Odată cu ieșirea din criză, și căsătoriile au revenit pe un trend pozitiv, semn că românii au început să aibă din nou încredere în viitor și să își întemeieze o familie. Așa s-a ajuns ca, în 2018, să fie înregistrate 143292 căsătorii, cu 679 căsătorii mai multe decât în anul anterior. Rata nupțialității a ajuns, astfel, la 6,5 căsătorii la 1000 locuitori, cel mai ridicat nivel din ultimii 10 ani. In 1990, spre comparație, se înregistrau 8,3 căsătorii la 1000 de locuitori.

De ce amână tinerii tot mai mult căsătoria? Cum de s-a ajuns ca femeile, mai ales cele din mediul urban, să se căsătorească la o vârstă medie de 30 de ani, în creștere cu aproape 10 ani față de acum 30 de ani? Potrivit experților, motivele sunt multiple și au legătură cu schimbările majore prin care a trecut societatea românească. „Acum 30 de ani, căsătoria era un pas esențial pe care tinerii îl făceau, odată cu încheierea studiilor, cu găsirea unui loc de muncă. Era un eveniment social în care sentimentele erau în strânsă legătură cu obiceiurile, cu ideea de cămin, de siguranță, de familie tradițională, mai ales în mediul rural. În 2020, societatea românească este mult mai sofisticată, mai ales în zonele urbane. Educaţia, influența mass-media \& social media, emanciparea

${ }^{22} \mathrm{http} / / /$ framesmedia.ro/2020/02/14/ (accesat la data de 14.12.2020).

${ }^{23} \mathrm{http}: / /$ framesmedia.ro/2020/02/14/ (accesat la data de 14.12.2020). 
Criza familiei în România contemporană.

O analiză sociologică, pastorală și catehetică

socială, aspirațiile legate de job, de carieră, opțiunile multiple legate de petrecerea timpului liber, însuși conceptul de întâlnire, de relație sentimentală, se prezintă la un alt nivel. Internetul, serviciile de dating au influențat în mod semnificativ apetitul românilor pentru relații de durată, un fenomen, de altfel, întâlnit la nivelul tuturor țărilor occidentale" ${ }^{24}$, afirmă Adrian Negrescu, managerul Frames.

Așa s-a ajuns ca vârsta medie la căsătorie, în anul 2018, să fie de 33,8 ani la bărbați și de 30,6 ani la femei. Spre comparație, cei mai tineri însurăței, în anul 1990, erau cei din mediul rural. Femeile se căsătoreau, în medie, la vârsta de 21,3 ani, iar bărbații la 24,8 ani. „Dincolo de condițiile sociale, de mentalitate, amânarea căsătoriilor trebuie pusă în legătură directă cu situația economică a cuplului. Achiziția unei locuințe reprezintă, în 2020, o adevărată provocare, mai ales pentru tineri. Contractarea unui credit este determinată de nivelul salarial, iar costurile vieții în comun generează o presiune pe care multe dintre cupluri reușesc cu greu să o suporte, astfel că amână căsătoria și conceperea unui copil o perioadă tot mai lungă de timp, în așteptarea îmbunătățirii situației financiare" 25 , arată analiza Frames.

Potrivit datelor INS, în 2018, cele mai multe căsătorii $(14,4 \%$ din numărul total de căsătorii) s-au încheiat de bărbații și femeile din grupa de vârstă 25-29 ani, urmate de cele încheiate de bărbații din aceeași grupă de vârstă cu femeile din grupa de vârstă 20-24 ani $(12,2 \%)$. În anul 2018 s-au înregistrat, în total, 143.292 căsătorii, cu 679 căsătorii mai multe decât în anul anterior. Numărul cel mai mare de căsătorii a fost înregistrat în București (24476 căsătorii), urmat de județul Iași (6641), Suceava (5179) și Timiș (5135), iar cel mai mic număr de căsătorii s-a înregistrat în județul Tulcea (1087 căsătorii) ${ }^{26}$.

Cele mai ridicate rate de nupțialitate (număr de căsătorii la 1000 de locuitori) s-au înregistrat în București (11,5\%o), județul Ilfov $(7,7 \%$ ) și județul Iași (7,0\%o), iar cele mai mici rate de

${ }^{24} \mathrm{http}: / /$ framesmedia.ro/2020/02/14/(accesat la data de 14.12.2020)

${ }^{25} \mathrm{http}$ ://framesmedia.ro/2020/02/14/(accesat la data de 14.12.2020)

26 https://insse.ro/cms/ro/content/evenimente-demografice-\%C3\%AEn-anul-2019 (accesat la data de 11.12.2020) 
nupțialitate s-au înregistrat în județul Tulcea $(4,6 \%$ ) și în județul Vâlcea $(3,4 \%$ ). La nivel european, România se situează printre țările cu o rată a nupțialității ridicată, de 7,3\%o, alături de Lituania (7,5\%), Cipru și Letonia (6,8\%o) și Malta (6,3\%o). Țările învecinate României, Bulgaria $(4,0 \%$ ) și Ungaria $(5,2 \%)$, au rate de nupțialitate mai mici decât ale României ${ }^{27}$.

Așadar, numărul căsătoriilor a început să scadă din 1990 (cu mici excepții), iar anul 2020 (atipic, din cauza pandemiei) a coborât aceste ceremonii sub 90000. Potrivit datelor INS, avem circa 900000 de cupluri care locuiesc în uniune consensuală $(13 \%$ din familiile de la noi $)^{28}$, fără a fi căsătorite. Numărul lor nu s-a modificat mult în ultimii 30 de ani, conform datelor oficiale.

\section{Ce ne spune Barometrul vieții religioase din România (decembrie 2020)}

La sfârşitul lunii decembrie 2020, a fost publicat Barometrul vieții religioase din România, realizat de Secretariatul de Stat pentru Culte în colaborare cu Academia Română ${ }^{29}$. Este cea mai recentă privire de ansamblu, obiectivă, referitoare la cum arată în prezent viața religioasă în România. Multe dintre întrebările formulate corespund celor din cercetarea PewResearch Center din mai 2017, fiind astfel util a compara cele două cercetări pentru a afla dacă parametrii esențiali ai vieții religioase s-au schimbat sau nu în ultimii trei ani.

$O$ întrebare interesantă se referă la percepția gradului de religiozitate. $33,6 \%$ cred că românii sunt mai religioși decât înainte de $1989,36,8 \%$ cred că sunt mai religioși, iar 28,8\% cred că

27 https://insse.ro/cms/ro/content/evenimente-demografice-\%C3\%AEn-anul-2019 (accesat la data de 11.12.2020)

$28 \mathrm{https}: / /$ insse.ro/cms/ro/content/evenimente-demografice-\%C3\%AEn-anul-2019 (accesat la data de 11.12.2020)

29 https://larics.ro/wp-content/uploads/2020/12/Barometrul-vietii-religioase-LARI CS-CCSL-16.12.2020.pdf (accesat la data de 11.12.2020). 
Criza familiei în România contemporană.

O analiză sociologică, pastorală și catehetică

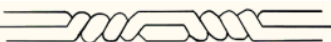

atitudinea față de religie nu s-a schimbat ${ }^{30}$. Cercetarea PewResearch Center nu a studiat acest aspect în România, dar, în fostele țări comuniste cu majorități ortodoxe unde a fost pusă această întrebare, răspunsurile sunt contradictorii: unele au devenit mai religioase, altele nu. Greu de spus ce s-a întâmplat în România din acest punct de vedere, o afirmație care corespunde adevărului dacă ținem cont de polarizarea extremă a răspunsurilor. Cel mai indicat este a da un răspuns în funcție de anumite categorii de vârstă.

La întrebarea dacă se consideră o persoană religioasă, $63,8 \%$ răspund afirmativ, iar $26,6 \%$ răspund mai degrabă afirmativ. Cumulat, este vorba de 90,4\%. Procentul corespunde celor care răspund afirmativ la întrebarea dacă cred în Dumnezeu $(90,2 \%)^{31}$. În cercetarea PewResearch Center, 95\% dintre români răspundeau afirmativ la această întrebare, ceea ce denotă, din această perspectivă, un grad foarte redus de secularizare în ultimii ani. România se afla în 2017 pe locul 2, după Georgia (99\%) și la egalitate cu Armenia și Republica Moldova. Potrivit cercetării PewResearch Center, $21 \%$ dintre români merg la biserică săptămânal (cel mai ridicat procent din țările cu majoritate ortodoxă). În cercetarea din decembrie 2020, 36,1\% declară acest lucru, ceea ce indică un grad mai ridicat de religiozitate față de 2017. Aceeaşi concluzie apare și dacă se ia în considerare întrebarea referitoare la cei care se roagă zilnic. În 2017 procentul acestora era de $44 \%$ (locul trei în rândul țărilor cu majoritate ortodoxă, după Republica Moldova - 48\% și Armenia - 45\%), în 2020 procentul a crescut la $68,2 \%$.

La întrebarea cum se transmit valorile religioase în familie, sondajul din 2017 este preocupat doar de transmiterea în viitor a acestora, $100 \%$ dintre românii de religie ortodoxă afirmând că își vor educa copiii în aceeași religie. Sondajul din 2020 este preocupat mai degrabă de cum au fost transmise până în prezent valorile

30 https://larics.ro/wp-content/uploads/2020/12/Barometrul-vietii-religioase-LARI CS-CCSL-16.12.2020.pdf (accesat la data de 20.12.2020)

$31 \mathrm{https}: / /$ larics.ro/wp-content/uploads/2020/12/Barometrul-vietii-religioase-LARI CS-CCSL-16.12.2020.pdf (accesat la data de 20.12.2020) 
religioase, 48,2\% dintre cei intervievați afirmând că provin din părinți foarte religioși ${ }^{32}$.

La întrebarea dacă educația religioasă este necesară în şcoli, 72,8\% răspund afirmativ ${ }^{33}$. Coroborând cele două cercetări, putem afirma că familiile nu încurajează deloc schimbarea religiei în cazul copiilor, chiar și în cazul acelor familii compuse din părinţi care nu sunt foarte religioși. Școala este văzută ca un loc complementar de transmitere a valorilor religioase care se transmit iniţial în familie. Ambele cercetări au în vedere întrebarea dacă religia este fundamentală pentru identitatea națională. În versiunea PewResearch Center din 2017, 74\% dintre români au răspuns afirmativ, în cercetarea din 2020 doar 58,6\% au răspuns afirmativ.

\section{În loc de concluzii}

PF Daniel, Patriarhul Bisericii Ortodoxe Române, atrăgea atenţia asupra gravelor pericole care amenință sănătatea familiei în vremea noastră: „Din punct de vedere teologic-pastoral, observăm cât de expuse, solicitate și adesea amenințate sunt identitatea, coeziunea și armonia familiei creștine azi, în fața crizei economice (sărăcie, șomaj, nesiguranță etc.), a crizei morale (laxism, libertinaj, senzualism pornografic, dezordini erotice ridicate la rang de normalitate, prostituție din rațiuni comerciale, trafic de copii, divorț, droguri etc.), a crizei spiritual-religioase (sectarism fanatic, prozelitism agresiv, sincretism confuz, relativism doctrinar, indiferentism nihilist etc.). Pe de altă parte, credința creștină este întotdeauna izvor de speranță și de putere spirituală care ne ajută să biruim greutățile și încercările vieții. În acest sens, criza, ca stare de judecată pentru un lucru sau o stare incompatibilă cu voia lui Dumnezeu, este în același timp o chemare acută la schimbarea în bine, o șansă pentru un început nou"34.

32 https://larics.ro/wp-content/uploads/2020/12/Barometrul-vietii-religioase-LARI CS-CCSL-16.12.2020.pdf (accesat la data de 20.12.2020)

33 https://larics.ro/wp-content/uploads/2020/12/Barometrul-vietii-religioase-LARI CS-CCSL-16.12.2020.pdf (accesat la data de 20.12.2020)

34 ÎPS DANIEL, Mitropolitul Moldovei și Bucovinei, „Familia creștină-Biserica de acasă”, în ***Familia creștină azi, Iași, Edit.Trinitas, 1995, p. 5-6. 
Criza familiei în România contemporană.

O analiză sociologică, pastorală și catehetică

Așa cum se observă prin intermediul statisticilor și a sondajele prezentate mai sus, dinamica familiei este influențată, în sens pozitiv sau negativ, de mai mulți factori. Problematica migrației, a abandonului copiilor, a scăderii natalității și a nupțialității, văzute prin prisma impactului social la adresa familiilor din România, este una extrem de serioasă în prezent și pe termen lung.

În primul rând, familia este locul privilegiat unde se face educația durabilă și integrală a copiilor. Nici o societate nu poate exista fără o educație adecvată a cetățenilor săi. Părinții, frații și celelalte rude ajută la educarea copiilor chiar din momentul în care aceștia se nasc.În al doilea rând, familia este o sursă fundamentală de sprijin fizic și emoțional pentru membrii săi. Le oferă hrană, îmbrăcăminte, adăpost, dragoste, confort și ajutor în momentele de suferință, elemente esențiale de care fiecare ființă umană are nevoie. În al treilea rând, familia oferă membrilor săi o identitate socială. Copiii sunt născuţi în aceeași clasă socială, rasă, etnie și religie ca și părinții lor. Identitatea socială este uneori decisivă pentru reușita lor în viață.

Fiind o micro-societate, familia suferă modificări în propria dinamică din cauza schimbărilor survenite în societate și în mediile în care membrii acesteia trăiesc și își desfășoară activitatea, însă, prin mecanismul de autoreglare, de adaptare, prin comunicare, membrii acesteia îi pot reda stabilitatea. Conform unor studii recente efectuate de specialiști în sănătate comportamentală, faptul că un copil trăiește într-o familie cu ambii părinți, are credință religioasă, o identitate culturală la care este conectat și un înalt grad al nivelului de valori, reprezintă factori de protecție care îl ajută să facă faţă cu succes încercărilor din viață și să neutralizeze factorii de risc.

$\cos 80$

\section{Bibliografie}

\section{Cărți, studii și articole}

1. DIACONU, Mihai Sociologia educației, București, Edit. ASE, 2004.

2. GAVRILUȚĂ, Nicu, „Criza spirituală a satului românesc contemporan. Diagnostic și terapii religioase", în †VARLAAM Ploieșteanul, Nicușor BELDIMAN (coord.), Satul românesc: vatră 
a plămădirii, păstrării și promovării ființei naționale și a credinței ortodoxe, București, Edit. Basilica, 2019.

3. DANIEL, Mitropolitul Moldovei și Bucovinei, „Familia creștinăBiserica de acasă”, în ***Familia creștină azi, Iași, Edit.Trinitas, 1995.

4. PoP, Vasile, „Familia creștină - imperativul misionar al Bisericii în societatea contemporană. Accente și remedii misionare", în Glasul Bisericii, 1-6/2018, p. 111.

5. PoPOVICI, Dumitru, Sociologia educației, Iași, Edit. Institutul European, 2003.

6. STĂNCIULESCU, Elisabeta, Sociologia educației familiale, vol. I, Iași, Edit. Polirom, 2002.

\section{Surse web}

7. https://m.adevarul.ro/news/eveniment/cum-ajuns-romanii-loculdoiin-lume-emigratie-motive-consecinte-

1_599473bc5ab6550cb80c2cdc/index.html (accesat la data de 23.11.2020).

8. https://www.mediafax.ro/social/fenomenul-braila-usr-ii-cereecaterinei-andronescu-stoparea-fenomenului-de-excluziuneeducationala-in-scoli-18230141 (accesat la data de 22.10.2020).

9. https://www.academia.edu/36446004/ROMANIAN_MIGRATION _FIELDS_ON_THE_MOVE (accesat la data de 21.10.2020).

10. http://www.miscareamoldova.ro/adevarul-ro-efectele-depopulariicauzate-de-migratia-economica-in-occident/ (accesat la data de 07.12.2020).

11. https://www.unicef.org/Raport_final_HAC.pdf (accesat la data de 10.01.2021).

12. https://insse.ro/cms/ro/content/mi\%C $\% 99$ carea-natural\%C4\%83popula\%C8\%9Biei-72 (accesat la data de 10.02.2021).

13. http://framesmedia.ro/2020/02/14/ (accesat la data de 14.12.2020)

14. https://insse.ro/cms/ro/content/evenimente-demografice$\%$ C3\%AEn-anul-2019 (accesat la data de 11.02.2021)

15. https://larics.ro/wp-content/uploads/2020/12/Barometrul-vietiireligioase-LARICS-CCSL-16.12.2020.pdf (accesat la data de 11.02.2021). 